\title{
Laparoscopic colecistectomy: anestesthetic implications in the elderly patient
}

\author{
A Paratore $^{1 *}$, O Minutolo ${ }^{2}, \mathrm{G}$ Buscema ${ }^{1}$, L Ferrigno ${ }^{1}$, V Minutolo $^{2}$ \\ From de Senectute: Age and Health Forum \\ Catanzaro, Italy. 5-7 December 2009
}

\section{Background}

The gallbladder stone is $20-40 \%$ of geriatric diseases. In elderly patients with limited cardiac reserve the pneumoperitoneum determines dangerous alterations of the cardiac output and other hemodynamic variables. The frequent co-morbidity in elderly people leads to a severe prognosis in these patients with surgical high mortality and morbidity rates in open surgery (1) otherwise the laparoscopic procedure is followed by lower mortality and morbidity rates $(0-0.6 \%$ vs $1.4 \%)$. $(2,3,4)$. The gradual abdominal insufflation to $12 \mathrm{mmHg}$ followed by a limited 10 degree head-up tilt is associated with cardiovascular stability in elderly ASA III patients (5).

The aim of our study was to analyze hemodynamic modifications during surgical treatment by laparoscopic colecistectomy and the anesthetic implications.

\section{Materials and methods}

121 patients aged over 65 years old were analyzed who underwent laparoscopic cholecistectomy . The operation was conducted with a low pressure of $\mathrm{CO} 2$ (8-10 $\mathrm{mmHg}$ ).We observed the hemodynamic trend during the anesthesia: blood pressure, heart rate, respiratory rate, Tidal Volume and end Tidal $\mathrm{CO}_{2}$. Blood gas exchanges were analyzed.

\section{Results}

After 15 minutes of pneumoperitoneum the blood pressure was higher $(123 \pm 18 \mathrm{mmHg})$ whereas the heart rate was the same.

$\mathrm{PcO} 2$ and end Tidal $\mathrm{CO}_{2}$ was higher respectively 15 and 60 minutes after pneumoperitoneum. The end Tidal $\mathrm{CO}_{2}$ gap was low $(3.5 \mathrm{mmHg})$ during the surgery. In the postoperative period the blood exchanges showed the same value as the preoperative period while there was no $\mathrm{PAO}_{2}$ modification during the procedure.

\section{Conclusions}

Our study showed the safety and the effectiveness of the laparoscopic cholecistectomy in elderly patients. Complications were not observed in the postoperative period.

\section{Author details}

'U.O.C. Anesthesia and Intensive Care Hospital "Guzzardi" di Vittoria (Rg), Italy. ${ }^{2}$ Department of Surgical Sciences, Organ Transplantations and Advanced Technologies, University of Catania, Via Santa Sofia, 95123,

Catania, Italy.

\section{Published: 19 May 2010}

\section{References}

1. Farsi M, Bini M, Calistri M, Caridi A, Miranda E, Moraldi L, Pallabazzer G, Favi P: Acute biliopancreatic diseases in the elderly patient. $G$ Gerontol 2004, 52:96-110.

2. Leardi S, Delmonaco S, Maira E, Pietroletti R, Chiaretti M, De Milito R, Catani M, Simi M: La colecistite acuta nell'ultrasettantenne. Minerva Chir 2001, 56(z):501-6.

3. Nenner RP, Imperato PJ, Alcorn CM: Complications of laparoscopic cholecystectomy in a geriatric population group. N Y State J Med 1992, 92:518-529.

4. Feldman MG, Russel JC, Lynch JT, Mattie A: Comparison of mortality rates for open and closed cholecystectomy in the elderly: Connecticut statewide survey. J Laparoendosc Surg 1994, 4:165-171.

5. Dhoste K, Lacoste L, Karayan J, Lehuede MS, Thomas D, Fusciardi J: Haemodynamic and ventilatory changes during laparoscopic cholecystectomy in elderly ASA III patients. Can J Anaesth 1996, 43:783-788.

doi:10.1186/1471-2318-10-S1-A112

Cite this article as: Paratore et al:: Laparoscopic colecistectomy: anestesthetic implications in the elderly patient. BMC Geriatrics 2010 10(Suppl 1):A112. 